\title{
Studenci pedagogiki Akademii Pedagogiki Specjalnej w Warszawie i ich orientacje edukacyjne. Prezentacja wyników badań własnych
}

\begin{abstract}
The following article comprises the description of methodology and the presentation of the results of individual research. The aim of the realised project was recognising and characterising the educational orientations of pedagogy students. The author used the Polish adapted version of W.F. O’Neill's questionnaire on ideological orientations to survey the educational orientations of students. The questionnaire estimates six detailed educational ideologies. This article presents the results of a survey concluded on a group of 506 students of the Maria Grzegorzewska University in Warsaw. Among students the choice of liberal educational ideology is predominant. The number of followers of radical right-wing educational ideologies is marginal.
\end{abstract}

\section{Key words:}

educational orientations, ideologies, students, liberalism, conservatism

1 Błażej Przybylski, Katedra Socjologii Edukacji, Wydział Nauk Pedagogicznych, Akademia Pedagogiki Specjalnej im. Marii Grzegorzewskiej, Polska, blazej.przybylski@wp.pl.

2 Artykuł powstał w ramach realizacji projektu „Orientacje i ideologie edukacyjne w programach politycznych i w opiniach studentów pedagogiki Akademii Pedagogiki Specjalnej w Warszawie” (BSTP 19/15-I) w Akademii Pedagogiki Specjalnej im. Marii Grzegorzewskiej w Warszawie. 


\section{WPROWADZENIE}

Badacze z zaciekawieniem przyglądają się całemu spectrum życia młodzieży: jej kulturze, dążeniom, planom, stylom życia, orientacjom itp. Wyrazem zainteresowania nauki populacją młodzieży jest coraz większa liczba opracowań dotyczących aspiracji, celów, motywacji edukacyjnych czy wartości preferowanych przez młode pokolenie. Znaczna ich część prezentuje i analizuje światopoglądy i wyznawane ideologie społeczeństwa polskiego, w tym młodzieży (np. Czapiński, Panek, 2013; CBOS, 2013; Szafraniec, 2011). Traktują one jednak orientacje edukacyjne raczej marginalnie, koncentrując się w pierwszym rzędzie na badaniu różnych zjawisk i postaw w kontekście gospodarki, ocenie funkcjonowania demokracji, czy też ogólnych orientacjach życiowych.

Poznanie opinii młodych na temat rzeczywistości szkolnej, celów i pożądanego modelu edukacji stanowi przedsięwzięcie ważne i inspirujące badaczy do przemyśleń, zarówno w kontekście funkcjonowania edukacji formalnej we współczesności, jak i jej przyszłego kształtu. Szczególnie ciekawych spostrzeżeń można spodziewać się po studentach uczestniczących w edukacji na poziomie akademickim, patrzących już z pewnego dystansu na edukację podstawową, gimnazjalną i licealną. Wśród akademickiej społeczności studentów prawdopodobnie najbardziej przemyślane refleksje na temat edukacji są udziałem tych, którzy wybrali pedagogikę jako kierunek studiów.

\section{CEL BADANIA}

Celem badania było poznanie oraz charakterystyka orientacji edukacyjnych studentów pedagogiki. Skoro orientacje życiowe to „charakterystyczne dla jednostki, grupy nastawienie do różnych dziedzin życia i do własnego »ja « wyrażające się w różnym nasileniu, odmianach deklarowanej lub/i rzeczywistej aktywności” (Gańczarczyk, 1994, s. 16), możemy przyjąć, że orientacje edukacyjne to nic innego jak nastawienie jednostek lub całych grup do edukacji.

Określenie orientacji edukacyjnych studentów pedagogiki niesie ze sobą dużą wartość poznawczą, gdyż - z racji kierunku studiów - najprawdopodobniej będą oni w przyszłości wykonywać zawód nauczyciela lub zajmować inne stanowiska w mniejszym lub większym stopniu związane z systemem oświaty. Diagnoza orientacji edukacyjnych młodych dorosłych studiujących pedagogikę pozwala na określenie dominujących ideologii w badanej grupie. 


\section{OPIS NARZĘDZIA BADAWCZEGO}

Do pomiaru orientacji edukacyjnych studentów wykorzystano spolszczoną wersję kwestionariusza orientacji ideologicznych autorstwa W.F. O’Neilla (został on zaadaptowany w wersji polskiej przez Z. Melosika i P. Kwiecińskiego) (Kwieciński, 2012, s. 58) $)^{3}$.

Zgodnie z koncepcją Autora kwestionariusz ten jest przeznaczony do pomiaru ośmiu typów ideologii, w tym sześciu ideologii edukacyjnych (w poniższej tabeli są one odpowiednie ponumerowane).

Tabela 1. Zaproponowany podział ideologii

\begin{tabular}{|c|c|c|c|c|c|c|c|}
\hline \multicolumn{8}{|c|}{ IDEOLOGIE } \\
\hline \multicolumn{4}{|c|}{ konserwatyzm zbiorczy (3) } & \multicolumn{4}{|c|}{ Liberalizm zbiorczy } \\
\hline \multicolumn{3}{|c|}{$\begin{array}{c}\text { konserwatywne ideologie eduka- } \\
\text { cyjne (1) }\end{array}$} & \multicolumn{2}{|c|}{$\begin{array}{c}\text { ideologie ogólne } \\
\text { (2) }\end{array}$} & \multicolumn{3}{|c|}{$\begin{array}{c}\text { liberalne ideologie edukacyjne } \\
(1)\end{array}$} \\
\hline $\begin{array}{l}\text { funda- } \\
\text { menta- } \\
\text { lizm (F) }\end{array}$ & $\begin{array}{l}\text { intelektu- } \\
\text { alizm (I) }\end{array}$ & $\begin{array}{l}\text { konser- } \\
\text { watyzm } \\
\text { edukacyj- } \\
\text { ny }(\mathrm{Ke})\end{array}$ & $\begin{array}{l}\text { konser- } \\
\text { watyzm } \\
\text { ogólny } \\
\text { (Ko) }\end{array}$ & $\begin{array}{l}\text { liberalizm } \\
\text { ogólny } \\
\text { (Lo) }\end{array}$ & $\begin{array}{l}\text { liberalizm } \\
\text { edukacyj- } \\
\text { ny (Le) }\end{array}$ & $\begin{array}{l}\text { ideologia } \\
\text { emancy- } \\
\text { pacyjna } \\
\text { (E) }\end{array}$ & $\begin{array}{l}\text { anar- } \\
\text { chizm } \\
\text { edukacyj- } \\
\text { ny (A) }\end{array}$ \\
\hline
\end{tabular}

Źródło: Opracowanie własne na podstawie kwestionariusza O’Neilla.

Można wyodrębnić trzy poziomy analizy:

1) pierwszy z nich dotyczy szczegółowych ideologii edukacyjnych: każdej z sześciu ideologii edukacyjnych przypisano 14 twierdzeń, zestawionych w kwestionariuszu w sposób przypadkowy. Autor wyróżnia: fundamentalizm (F), intelektualizm (I), konserwatyzm edukacyjny (Ke), liberalizm edukacyjny (Le), ideologię emancypacyjną (E) oraz anarchizm edukacyjny (A). W dalszej części tekstu będę je nazywał (szczegółowymi) ideologiami edukacyjnymi, w celu rozróżnienia ich od dwóch zbiorczych ideologii;

2) na drugim poziomie w kwestionariuszu zostały wyszczególnione dwie ideologie, nazwane ideologiami ogólnymi: ideologia konserwatyzmu ogólnego (Ko) oraz liberalizmu ogólnego (Lo). Każda z ideologii reprezentowana jest

3 Za udostępnienie polskiej wersji kwestionariusza dziękuję Profesorowi Zbigniewowi Kwiecińskiemu, który nie tylko zezwolił na skorzystanie ze wcześniej stosowanego przez siebie narzędzia, ale także służył mi cennymi radami. Przy opisie ideologii edukacyjnych wyszczególnionych przez O’Neilla, autora kwestionariusza, posiłkuję się również prywatnymi notatkami Z. Kwiecińskiego. Przegląd wyników badania z zastosowaniem kwestionariusza O’Neilla można znaleźć w książce Z. Kwiecińskiego (2000). 
w kwestionariuszu za pomocą 10 twierdzeń przetasowanych i ułożonych przypadkowo;

3) na trzecim poziomie osiem wyróżnionych ideologii można podporządkować dwóm ideologiom zbiorczym. Pierwsza z nich skupia konserwatywne ideologie (F, I, Ke, Ko), zaś druga - liberalne (postępowe) ideologie (Lo, Le, E, A).

Kwestionariusz zawiera 104 twierdzenia dotyczące filozofii edukacji i wizji szkoły, w szczególności aspektów składających się na ideologie edukacyjne, jak: ogólny cel edukacji, zadania i funkcje szkoły, administracja i kontrola systemu szkolnego, charakter programów szkolnych, treści programowe oraz metody uczenia i oceniania (O’Neill, 1981, s. 21). Do każdego z twierdzeń można było odnieść się na pięciostopniowej skali, na której „,-2” oznacza „,w pełni się nie zgadzam”; „-1” „nie zgadzam się”; „,0” - ,jestem niepewny, niezdecydowany lub obojętny”; „1” „zgadzam się”; zaś „2” - „w pełni się zgadzam”.

Tabela 2. Przykładowe twierdzenia zawarte w kwestionariuszu dla poszczególnych skal

\begin{tabular}{|c|c|}
\hline Typ ideologii & Przykładowe twierdzenia zawarte w kwestionariuszu \\
\hline fundamentalizm & $\begin{array}{l}\text { 1) Szkoły powinny kształtować charakter moralny i koncentrować się } \\
\text { na rozwijaniu właściwych zasad osobistych uczniów. } \\
\text { 2) Na terenie edukacji powinno wrócić się do wykorzystywania bar- } \\
\text { dziej tradycyjnych zasad i praktyk. } \\
\text { 3) Nauczyciel powinien być wzorem doskonałości zarówno moralnej, } \\
\text { jak i akademickiej. }\end{array}$ \\
\hline $\begin{array}{l}\text { intelektualizm } \\
\text { edukacyjny }\end{array}$ & $\begin{array}{l}\text { 1) Uczniowie powinni stosować się do absolutnych i stałych norm } \\
\text { moralnych, opartych na absolutnych i stałych przekonaniach intelek- } \\
\text { tualnych. } \\
\text { 2) Szkoła powinna ograniczać się w możliwie największym stopniu } \\
\text { do doskonalenia intelektu, pozostawiając takim instytucjom spo- } \\
\text { łecznym, jak Kościół i rodzina, inne ważne aspekty indywidualnego } \\
\text { rozwoju. } \\
\text { 3) Ponieważ prawda, wartości i natura człowieka są względnie } \\
\text { niezmienne, to program szkolny nie powinien się zmieniać w zna- } \\
\text { czącym stopniu. }\end{array}$ \\
\hline $\begin{array}{l}\text { konserwatyzm } \\
\text { edukacyjny }\end{array}$ & $\begin{array}{l}\text { 1) Źródłem szczęścia człowieka jest - ostatecznie - przystosowanie się } \\
\text { do przeważających wzorów przekonań i zachowań. } \\
\text { 2) Zadaniem szkoły powinno być przede wszystkim przekazywanie } \\
\text { informacji i umiejętności, które umożliwią dzieciom przetrwanie } \\
\text { i odniesienie sukcesu w ramach istniejącego porządku publicznego. } \\
\text { 3) Uczniowie powinni być kształceni na dobrych obywateli, przede } \\
\text { wszystkim przy uwzględnianiu przeważających w naszej kulturze } \\
\text { poglądów na istotę dobrego obywatelstwa i właściwego postępowa- } \\
\text { nia. }\end{array}$ \\
\hline
\end{tabular}




\begin{tabular}{|c|c|}
\hline Typ ideologii & Przykładowe twierdzenia zawarte w kwestionariuszu \\
\hline $\begin{array}{l}\text { liberalizm } \\
\text { edukacyjny }\end{array}$ & $\begin{array}{l}\text { 1) Edukacja jest z istoty swojej celem samym w sobie, jest życiem: } \\
\text { tylko na marginesie jest ona przygotowaniem dla jakiś przyszłych } \\
\text { form aktywności } \\
\text { 2) Szkoły powinny koncentrować się na niepowtarzalnej osobowości } \\
\text { dziecka, dostosowując się do specyficznego charakteru każdej } \\
\text { jednostki. } \\
\text { 3) Szkoły każdego szczebla powinny być przede wszystkim zaintere- } \\
\text { sowane rozwijaniem zdolności dziecka do rozwiązywania przez nie } \\
\text { własnych problemów. }\end{array}$ \\
\hline $\begin{array}{l}\text { ideologia } \\
\text { emancypacyjna }\end{array}$ & $\begin{array}{l}\text { 1) Szkoły powinny kłaść nacisk na krytyczną analizę i ocenianie prze- } \\
\text { ważających przekonań i zachowań społecznych. } \\
\text { 2) Nauczyciel powinien być wzorem intelektualnego i społecznego } \\
\text { zaangażowania. } \\
\text { 3) Najlepsze społeczeństwo to społeczeństwo demokratycznego } \\
\text { socjalizmu, które dąży do uzyskania maksymalnej sprawiedliwości } \\
\text { społecznej dla wszystkich obywateli. }\end{array}$ \\
\hline $\begin{array}{l}\text { anarchizm } \\
\text { edukacyjny }\end{array}$ & $\begin{array}{l}\text { 1) Ogólnie mówiąc, dziecko w wieku szkolnym powinno samo } \\
\text { osądzić, czy dana forma edukacji i w ogóle jakakolwiek edukacja } \\
\text { odpowiada najlepiej jego potrzebom osobistym. } \\
\text { 2) Obowiązkowe kształcenie powinno być zastąpione przez swobodną, } \\
\text { lecz nieprzymuszoną dostępność edukacji dla wszystkich ludzi. } \\
\text { 3) Formalne kształcenie jest zasadniczo niepotrzebne, a jego wkład } \\
\text { w całkowite doświadczenie ludzkie jest niewielki lub żaden. }\end{array}$ \\
\hline
\end{tabular}

Źródło: Opracowanie własne na podstawie zaadaptowanej wersji kwestionariusza O’Neilla.

\section{ZARYS ZAPROPONOWANYCH IDEOLOGII EDUKACYJNYCH}

Autor kwestionariusza W.F. O’Neill wyróżnia sześć szczegółowych ideologii edukacyjnych; ich założenia ujęte są w poszczególnych twierdzeniach zawartych w kwestionariuszu. Przedstawiam je poniżej w krótkim zarysie:

1) Fundamentalizm (F) - w edukacji należy wrócić do starych, sprawdzonych zasad i wartości, mających charakter stały, bezwarunkowy i nieusuwalny. Szkoły winny propagować tradycyjny porządek, wartości oraz wzorce znane z przeszłości; ich zadanie polega przede wszystkim na kształtowaniu odpowiedniej moralności i patriotyzmu, opierającego się na gloryfikacji wierzeń, symboli i wzorów osobowych oraz dbałości o odrodzenie i pielęgnowanie zaangażowania religijnego. Nauczyciel powinien stanowić wzór intelektualny i moralny. Oczekuje się od niego autorytarnego zarządzania klasą; stanowczego i jednoznacznego formułowania poleceń;

2) intelektualizm (I) - edukacja powinna pomagać w rozpoznawaniu i przekazywaniu prawdy oraz obiektywnego sensu i znaczenia życia. Zdobycie 
i poszerzanie wiedzy jest nadrzędnym celem człowieka. Umożliwienie jednostce realizacji tego celu stanowi zadanie placówek edukacyjnych. Szkoła ma przede wszystkim pełnić funkcje dydaktyczne, ograniczając się do przekazywania niepodważalnej, potwierdzonej naukowo wiedzy; jej zadaniem jest doskonalenie ludzkiego intelektu. Zadanie nauczyciela polega na przekazie wiedzy. Dla uczniów winien on być wzorem mądrości oraz nieprzeciętnej inteligencji;

3) konserwatyzm edukacyjny (Ke) - fundamentalne wartości to stabilizacja i porządek. Wśród nich liczą się najbardziej zdroworozsądkowe przekonania większości społeczeństwa. Konserwatyzm odrzuca radykalne, nowe projekty zmian. Cel edukacji szkolnej stanowi transmisja kultury, wspierająca przystosowanie uczniów do dominujących wzorów zachowań społecznych, które warunkują adaptację w środowisku oraz umożliwiają osiągnięcie sukcesu. Szkoła ma propagować tradycyjne wartości, odrzucając wszelkie innowacje i eksperymenty. Sprawdzone działania i tradycyjne wzory zachowania są najwłaściwszym drogowskazem postępowania. Odpowiedzialny i rozważny nauczyciel winien swoją postawą przeciwdziałać niepotrzebnym zmianom. Dziecko z kolei wymaga zwłaszcza kierowania i dyscypliny;

4) liberalizm edukacyjny (Le) - edukacja stanowi wartość autoteliczną. Celem edukacji jest wspieranie wyborów jednostki, z jej perspektywy słusznych i skutecznych. Szkoła powinna aktywnie uczestniczyć w rozwiązywaniu problemów, zarówno grupowych (np. dotyczących społeczności lokalnej czy klasy szkolnej), jak i indywidualnych; koncentrować się na jednostce, respektując niepowtarzalną osobowość każdego ucznia. Nauczyciel powinien motywować, pobudzać, zachęcać do rozwijania indywidualnych pasji, a nie tylko przekazywać wiedzę. Jako główny mankament szkoły postrzega się brak umiejętności motywowania uczniów do nauki;

5) ideologia emancypacyjna (E) - celem edukacji jest zbudowanie społeczeństwa sprawiedliwego i otwartego. Szkoła ma za zadanie kształcić krytycznych obywateli, podważających dominujące schematy zachowań i tzw. zdroworozsądkowe przekonania, oraz obywateli aktywnych, zdolnych do działania na rzecz przeobrażeń i refom społecznych. Powinna również popierać wszelkie propozycje zmian systemowych w kierunku budowy społeczeństwa bardziej egalitarnego i przyjaznego. Polityką oświatową powinna kierować niewielka grupa intelektualistów, potrafiących zdefiniować nowe cele edukacyjne. Nauczycielom w szkołach publicznych powinno 
przysługiwać prawo krytyki niesprawiedliwych warunków społecznych, uniemożliwiających pełen rozwój jednostki;

6) anarchizm edukacyjny (A) - obecny system szkolny powinien zostać zlikwidowany i zastąpiony przez edukację pozaformalną. To dziecko ma prawo decydować o tym, czego chce się uczyć, o ile w ogóle chce się uczyć. Nikt ani nic nie ma prawa narzucać komukolwiek obowiązku szkolnego. Wybór powinien należeć do jednostki, która we własnym zakresie może decydować o swoich ścieżkach edukacyjnych. Zadaniem placówek edukacyjnych jest propagowanie utopijnych wizji świata szczęśliwego, bez dominacji jednych nad drugimi, przymusu i zniewolenia. Szkoła ma rozwijać uczniów, by potrafili zbudować społeczeństwo, w którym instytucja szkolna w obecnym kształcie nie będzie już potrzebna, a ludzie będą uczyli się dobrowolnie. Dziś - z perspektywy tej ideologii - szkoły uczą jedynie konformizmu i uległości.

Powyższe zaproponowane szczegółowe ideologie edukacyjne uzupełniają dwie ideologie nazwane ogólnymi: konserwatyzm ogólny i liberalizm ogólny. Każdą z nich charakteryzuje 10 twierdzeń, bazujących na hasłach podstawowych dla danej orientacji politycznej. Z uwagi na cel artykułu i dalsze analizy nie zostają one w tym tekście szczegółowiej opisane.

\section{DOBÓR PRÓBY}

Badania przeprowadzone zostały wśród studentów Akademii Pedagogiki Specjalnej im. Marii Grzegorzewskiej w Warszawie. Dobór próby miał charakter losowy zespołowy. Bezpośrednio wylosowano do badania nie jednostki, lecz całe zespoły (w tym przypadku były to grupy ćwiczeniowe). Dobór losowy zespołowy zastosowano przede wszystkim ze względów organizacyjnych. Losowanie pojedynczych jednostek do badania znacznie utrudniłoby realizację oraz przebieg badania. Przy doborze próby postarałem się, by była ona reprezentatywna dla obu kierunków, dlatego też badaniami zostały objęte osoby na każdym roku studiów. Na każdym roku przebadano co najmniej dwie grupy ćwiczeniowe. Badanie nie zostało przeprowadzone wśród studentów studiów doktoranckich ani studiów niestacjonarnych.

W badaniu uczestniczyło 506 osób, w tym:

- 271 studentów studiów dziennych licencjackich oraz uzupełniających magisterskich na kierunku Pedagogika Ogólna, co stanowi 53,6\% badanej populacji

oraz 
- 235 studentów studiów dziennych licencjackich oraz uzupełniających magisterskich na kierunku Pedagogika Specjalna, co stanowi 44,4\% badanej populacji.

W badanej grupie przeważali studenci studiów licencjackich (58,7\%). Zdecydowaną większość badanych $(95,4 \%)$ stanowiły, z racji sfeminizowania obu kierunków studiów, kobiety. Aż 97,7\% badanych studentek i studentów urodziło się między 1990 a 1996 rokiem; w momencie prowadzenia badania mieścili się w przedziale wiekowym 19-25 lat.

\section{PRZEBIEG BADANIA}

Badanie prowadziłem w Akademii Pedagogiki Specjalnej im. Marii Grzegorzewskiej w Warszawie od grudnia 2015 do lutego 2016 roku. W badaniu orientacji ideologicznych i poglądów studentów na edukację posłużyłem się kwestionariuszem O’Neilla oraz wypełnianym bezpośrednio po teście autorskim kwestionariuszem ankiety ${ }^{4}$. Kolejność wypełniania obu narzędzi ma istotne znaczenie, dlatego zadbałem o to, by studenci w pierwszej kolejności wypełnili kwestionariusz, który został przygotowany w mniejszym niż ankieta formacie. Kwestionariusz O’Neilla oraz kwestionariusze autorskiej ankiety zostały rozdane w 27 grupach ćwiczeniowych. Początkowo zakładałem, że badanie przeprowadzę w 20 grupach (po dwie na każdym roku studiów licencjackich i magisterskich, co daje 10 grup na jednym kierunku studiów), jednak mniejsza liczebność grup spowodowana niską frekwencją lub mniejszą rzeczywistą liczebnością wylosowanych grup skłoniła mnie do doboru nowych zespołów badawczych. W efekcie próba była większa i, zgodnie ze wstępnymi założeniami, przekroczyła próg 500 osób. W każdej z grup, po uzyskaniu zgody prowadzącego zajęcia, badania przeprowadzałem osobiście, czuwając nad ich poprawną realizacją. Po wyrażeniu zgody na udział w badaniu studenci otrzymali komplet narzędzi badawczych. Najpierw wypełnili kwestionariusz, następnie przeszli do uzupełnienia znacznie krótszego autorskiego kwestionariusza ankiety. Przed przystąpieniem do badania otrzymali informację o celu badania oraz jego diagnostycznym, nie zaś oceniającym charakterze. Zostali również, zgodnie z instrukcją wstępną, poproszeni o ustosunkowanie się do

4 W poniższym artykule przedstawiam jedynie wyniki badania kwestionariuszem O’Neilla. Wyników tych nie łączę z wynikami otrzymanymi w kwestionariuszu ankiety autorskiej. Wyniki badania z zastosowaniem ankiety autorskiej zaprezentowane zostaną w kolejnych publikacjach. 
poszczególnych twierdzeń bez dłuższego namysłu, bezpośrednio po ich przeczytaniu. W badaniu chodziło bowiem o uchwycenie ogólnego wzoru myślenia, pozwalającego - w wyniku łącznej analizy odpowiedzi - na określenie dominacji konkretnej orientacji edukacyjnej. Badanie miało charakter anonimowy. Studenci zostali również poproszeni o postępowanie zgodne z instrukcją zawartą we wstępie ankiety.

\section{WYNIKI BADANIA}

\subsection{METODYKA WYZNACZENIA WYNIKU}

Jak wspomniano w podrozdziale 3 - opisującym narzędzie badawcze - w każdym stwierdzeniu badani mogli uzyskać od -2 do +2 punktów. Do obu zbiorczych skal zostały przypisane 52 twierdzenia, zatem minimalnie można było uzyskać minus 104, zaś maksymalnie plus 104 punkty. Dla każdego z badanych obliczano w kwestionariuszu sumaryczny wynik, zarówno na skalach zbiorczych, jak i szczegółowych. Skale szczegółowych ideologii edukacyjnych składały się z 14 twierdzeń, wobec tego można było otrzymać minimalnie minus 28, natomiast maksymalnie plus 28 punktów.

Każdemu z badanych, na podstawie jego ustosunkowania się do 104 twierdzeń zawartych w teście, przypisano dominującą ideologię, czyli tę ideologię, w której badany uzyskał największą liczbę punktów. Wyniki na konkretnej skali obliczano poprzez podsumowanie punktów. W ten sposób możliwe stało się określenie dominacji konkretnego światopoglądu nad pozostałymi.

\subsection{PARAMETRY NARZĘDZIA}

Rzetelność całego narzędzia, liczona za pomocą współczynnika alfa Cronbacha, wyniosła 0.892, co świadczy o zadowalającej rzetelności narzędzia ${ }^{5}$. Poniższa tabela prezentuje wartości współczynnika rzetelności dla uwzględnionych w badaniu skal.

5 W badaniach Aslihan Hanci Yerli rzetelność dla całego kwestionariusza (w tym przypadku zaadaptowanego na język turecki) wyniosła 0,92, a wartości dla poszczególnych skal wynosiły: fundamentalizm $(0,76)$; intelektualizm $(0,69)$; konserwatyzm edukacyjny $(0,76)$; liberalizm edukacyjny $(0,68)$; ideologia emancypacyjna $(0,68)$; oraz anarchizm $(0,62)$; w: A.H. Yerli $(2008)$. 
Tabela 3. Współczynnik Alfa Cronbacha dla kwestionariusza i poszczególnych skal

\begin{tabular}{lcc}
\hline & Alfa Cronbacha & Liczba twierdzeń \\
\hline cały kwestionariusz & 0,892 & 104 \\
\hline konserwatyzm zbiorczy & 0,833 & 52 \\
\hline liberalizm zbiorczy & 0,801 & 52 \\
\hline fundamentalizm & 0,704 & 14 \\
\hline intelektualizm & 0,544 & 14 \\
\hline konserwatyzm edukacyjny & 0,688 & 14 \\
\hline liberalizm edukacyjny & 0,592 & 14 \\
\hline ideologia emancypacyjna & 0,607 & 14 \\
\hline anarchizm edukacyjny & 0,626 & 14 \\
\hline
\end{tabular}

Źródło: Opracowanie własne.

\subsection{ORIENTACJE EDUKACYJNE STUDENTÓW PEDAGOGIKI APS. PREZENTACJA WYNIKÓW}

Wśród studentów znacznie dominują osoby o liberalnej orientacji edukacyjnej [podsumowanie czterech typów ideologii znajdujących się po prawej stronie na skali: (Lo)+(Le)+(E)+(A)] nad osobami o konserwatywnej orientacji [podsumowanie czterech typów ideologii znajdujących się po lewej stronie na skali: (F)+(I) $+(\mathrm{Ko})+(\mathrm{Ke})$ ]. Wyraźna przewaga zwolenników liberalizmu uwidacznia się na obu kierunkach, na każdym poziomie studiów i na każdym roku. Najmniejszą liczbę zwolenników ideologii liberalnej można zaobserwować na III roku Pedagogiki Specjalnej (,zaledwie” 76,9\%) oraz na I roku studiów uzupełniających magisterskich również na Pedagogice Specjalnej (80,8\%). Wśród pozostałych roczników dominacja orientacji liberalnej jest jeszcze wyraźniejsza.

Tabela 4. Dominacja wskazań na zbiorczy typ ideologii (N=405)

\begin{tabular}{llll}
\hline & Ogółem & kierunek & \\
\cline { 3 - 4 } & & Pedagogika Ogólna & $\begin{array}{l}\text { Pedagogika } \\
\text { Specjalna }\end{array}$ \\
\hline konserwatyzm & $11,1 \%$ & $8,3 \%$ & $14,4 \%$ \\
\hline liberalizm & $88,9 \%$ & $91,7 \%$ & $85,6 \%$ \\
\hline ogółem & $100,0 \%$ & $100,0 \%$ & 100,0 \\
\hline
\end{tabular}

Źródło: Opracowanie własne. 
Wykonany został także test chi-kwadrat, który wykazał, że istnieje istotna statystycznie zależność między kierunkiem studiów a dominacją zbiorczej ideologii (zależność istotna przy poziomie istotności 0,05; $\chi 2=3,754$, p=0,038).

Poniższy wykres (wykres 1) przestawia rozkład wyników na skali zbiorczego konserwatyzmu i zbiorczego liberalizmu. Do każdej ze skal zostały przypisane 52 twierdzenia, zatem minimalnie można było uzyskać minus 104, a maksymalnie 104 punkty. Wyniki zostały przedstawione w przedziałach 10 punktowych. Widać, iż częściej większy odsetek osób zdobywał większą liczbę punktów na skali liberalizmu niż konserwatyzmu (przesunięcie „liberalizmu” na prawo względem „konserwatyzmu”). Największy odsetek badanych (ponad 25\%) mieści się na skali liberalizmu w przedziale (31-40 pkt), z kolei na skali konserwatyzmu największy odsetek badanych uzyskał wynik w przedziale (11-20 pkt).

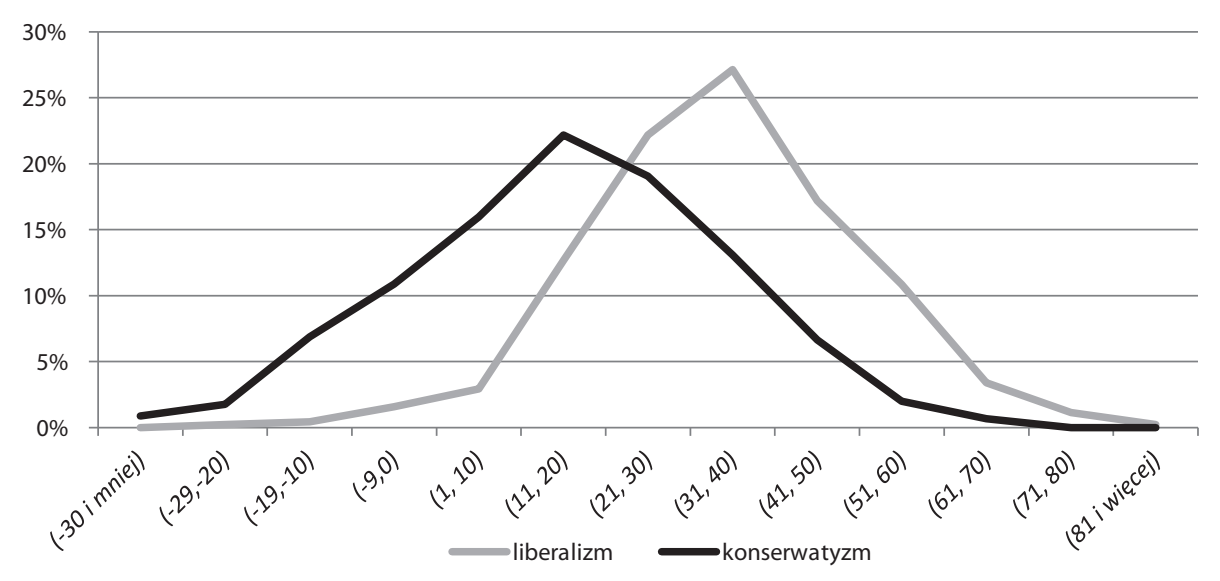

Wykres 1. Rozkład punktów otrzymanych na skali zbiorczej Źródło: Opracowanie własne.

Między obiema zbiorczymi ideologiami występuje wysoka i istotna statystycznie współzależność (współczynnik korelacji Pearsona wynosi 0,477. Wynik jest istotny na poziomie istotności 0,01). Świadczyć to może o „zamęcie światopoglądowym” i hybrydalnych konstrukcjach światopoglądowych badanych osób. Potwierdzają to także kolejne wyniki badań (patrz wykres 2).

Następnie badaną populację podzielono, ze względu na rozkład wyników na skali zbiorczego liberalizmu i zbiorczego konserwatyzmu, na kwartale. Cześć czwartą badanej populacji, która uzyskała najniższe wyniki na skali liberalizmu, przypisano do kategorii „najsłabszy liberalizm”, z kolei tę czwartą część, która 
uzyskała najwięcej punktów na tej skali - do grupy „najsilniejszy liberalizm”. Odpowiednio podzielono badane osoby ze względu na wynik otrzymany na skali konserwatyzmu. Analiza statystyczna wskazuje, że największą część wśród osób, które uzyskały najniższe wyniki na skali liberalnej stanowią badani, których wyniki na skali konserwatywnej uplasowały się na najniższym poziomie. Z kolei wśród osób o najsilniejszym liberalizmie dominują osoby cechujące się równocześnie najsilniejszym konserwatyzmem. Wynik ten może zaskakiwać. Mogłoby się bowiem wydawać, że im silniejsza postawa liberalna, tym słabsza konserwatywna. Tymczasem rozkład wyników wskazuje na zamęt światopoglądowy i/lub brak sprecyzowanych poglądów badanych na edukację. Z jednej strony respondenci mogą podchodzić w zróżnicowany sposób do konkretnych spraw w ramach poszczególnych ideologii zbiorczych. Przykładowo zgadzają się z celami konserwatystów, preferując jednakże liberalne treści i metody nauczania. Z drugiej zaś układ odpowiedzi wskazuje, że badani są bardziej skłonni aprobować podane twierdzenia, niż je odrzucać. Ponad połowa odpowiedzi (54\%) na wskazane w kwestionariuszu twierdzenia to: „zgadzam się” (36\%) lub „w pełni zgadzam się (18\%). Z kolei tylko 20\% ze wszystkich wskazań przypadło na odpowiedzi: „w pełni się nie zgadzam” (5\%) oraz „nie zgadzam się” (15\%). Zatem badani znacznie częściej przychylali się do wskazanych opinii, niż je odrzucali. Odpowiedź „0” oznaczająca ,jestem niepewny, niezdecydowany lub obojętny” została wybrana w 26\% przypadków a więc była drugą (po „1”) najczęściej udzielaną odpowiedzią.

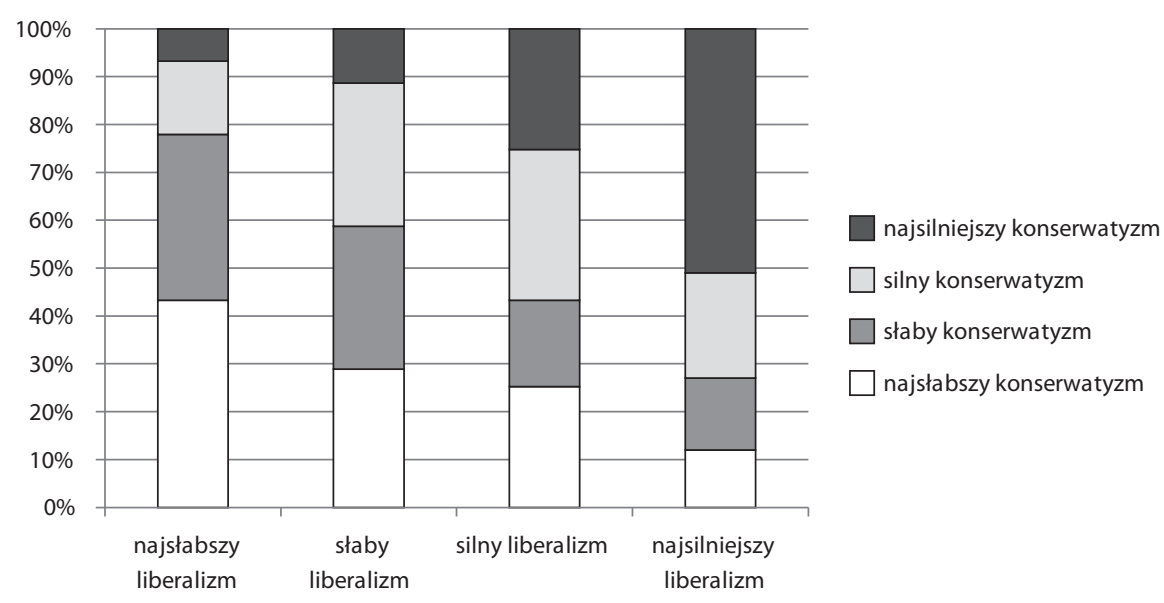

Wykres 2. Siła liberalizmu a siła konserwatyzmu

Źródło: Opracowanie własne. 
Wyniki twierdzeń z kwestionariusza dotyczące szczegółowych ideologii edukacyjnych potwierdzają wcześniejsze przypuszczenia, że wśród studentów APS zdecydowanie dominują osoby o liberalnych poglądach na edukację. Liberalizm edukacyjny cieszy się największym uznaniem studentów zarówno Pedagogiki Ogólnej, jak i Pedagogiki Specjalnej. Jedynie na III roku Pedagogiki Specjalnej odsetek zwolenników liberalizmu edukacyjnego spada poniżej 50\%; wśród pozostałych roczników odsetek jest wyższy (na niektórych latach przekracza znacznie 70\%). Silna przewaga orientacji liberalnej w edukacji nad pozostałymi wyróżnionymi typami jest cechą charakterystyczną studentów APS-u.

Zwraca uwagę stosunkowo wysoki odsetek osób o poglądach skrajnie lewicowych. Wśród prawie 20\% studentów dominuje przewaga orientacji liberacjonistycznej (ideologia emancypacyjna: 11\%) lub anarchistycznej (anarchizm edukacyjny: 8,4\%). Jak widać, trzy najpopularniejsze szczegółowe ideologie edukacyjne mieszczą się w nurcie liberalnym. Dla porównania, skrajni konserwatyści („fundamentalizm” + „intelektualizm”) stanowią tylko 7\% badanych. Poparcie dla konserwatyzmu edukacyjnego kształtuje się na poziomie niższym niż dla każdej z lewicowych ideologii edukacyjnych. Studenci obu kierunków, niezależnie od rocznika, pozostają zwolennikami liberalnych i lewicowych ideologii edukacyjnych. Można z pełnym przekonaniem stwierdzić, że orientacje skrajnie prawicowe występują wśród studentów APS jedynie marginalnie.

Tabela 5. Dominacja wskazań na konkretny typ ideologii edukacyjnej z uwzględnieniem kierunku studiów ( $\mathrm{N}=382)$

\begin{tabular}{lccc}
\hline & ogółem & \multicolumn{2}{c}{ kierunek } \\
\cline { 3 - 4 } & & Pedagogika Ogólna & Pedagogika Specjalna \\
\hline fundamentalizm & $3,9 \%$ & $2,9 \%$ & $5,1 \%$ \\
\hline intelektualizm & $3,1 \%$ & $3,4 \%$ & $2,8 \%$ \\
\hline konserwatyzm edukacyjny & $6,3 \%$ & $4,9 \%$ & $8,0 \%$ \\
\hline liberalizm edukacyjny & $67,3 \%$ & $68,4 \%$ & $65,9 \%$ \\
\hline ideologia emancypacyjna & $11,0 \%$ & $11,7 \%$ & $10,2 \%$ \\
\hline anarchizm edukacyjny & $8,4 \%$ & $8,7 \%$ & $8,0 \%$ \\
\hline ogółem & $100,0 \%$ & $100,0 \%$ & $100,0 \%$ \\
\hline
\end{tabular}

Źródło: Opracowanie własne.

Wykonano również test chi-kwadrat, który wykazał, że nie istnieje istotna statystycznie zależność między kierunkiem studiów a dominacją ideologii szczegółowej (zależność istotna przy poziomie istotności 0,05; x2=3,052, p=0,692). 
Wśród przeważającej większości (94,8\%) zwolenników liberalizmu edukacyjnego góruje zbiorczy liberalizm. Jedynie w przypadku większości fundamentalistów edukacyjnych dominującą orientacją jest zbiorczy konserwatyzm. We wszystkich pozostałych typach ideologii szczegółowej większość stanowią zwolennicy liberalizmu zbiorczego. Wśród zwolenników liberalizmu edukacyjnego oraz ideologii emancypacyjnej ponad 90\% stanowią osoby, u których dominuje zbiorczy liberalizm. Z kolei w przypadku zwolenników ideologii emancypacyjnej 100\% stanowią zwolennicy liberalizmu.

Tabela 6. Ideologie zbiorcze wśród zwolenników szczegółowych ideologii edukacyjnych

\begin{tabular}{|c|c|c|c|c|}
\hline & & \multicolumn{2}{|c|}{ ideologia zbiorcza } & \multirow[t]{2}{*}{ ogółem } \\
\hline & & liberalizm & konserwatyznm & \\
\hline \multirow{6}{*}{$\begin{array}{l}\text { ideologia } \\
\text { szczegółowa }\end{array}$} & fundamentalizm & $64,3 \%$ & $35,7 \%$ & $100 \%$ \\
\hline & intelektualizm & $40 \%$ & $60 \%$ & $100 \%$ \\
\hline & konserwatyzm edukacyjny & $38,1 \%$ & $61,9 \%$ & $100 \%$ \\
\hline & liberalizm edukacyjny & $5,2 \%$ & $94,8 \%$ & $100 \%$ \\
\hline & ideologia emancypacyjna & $2,6 \%$ & $97,4 \%$ & $100 \%$ \\
\hline & anarchizm edukacyjny & $0 \%$ & $100,0 \%$ & $100 \%$ \\
\hline
\end{tabular}

Źródło: Opracowanie własne.

Każda ze skal szczegółowych ideologii edukacyjnych, o czym wspomniałem na wstępie, składała się z 14 twierdzeń. Zdecydowanie najwyższą średnią punktów $(11,94)$ można zaobserwować na skali liberalizmu edukacyjnego. Również na tej skali występuje zdecydowanie najwyższa mediana i dominanta punktowa.

Najniższa średnia punktów przypada na „fundamentalizm” oraz „intelektualizm”, a zatem na obie skale mieszczące się w zbiorczym konserwatyzmie. W twierdzeniach składających się na skalę F opinie badanych okazały się też zdecydowanie najbardziej zróżnicowane (SD=6,911). Najmniejsze zróżnicowanie wystąpiło z kolei na skalach E (SD=5,197) oraz Le $(S D=5,335)$.

Kwestionariusz (o czym wspomniałem powyżej) zawierał 104 losowo wymieszane twierdzenia. Badani zostali poproszeni o możliwie szybkie ustosunkowanie się do każdego z nich. Mimo iż udzielali odpowiedzi, nie poświęciwszy głębszej refleksji poszczególnym twierdzeniom, można pokusić się o ogólne wnioski dotyczące opinii badanych na temat konkretnych wypowiedzi.

Z aprobatą największego odsetka badanych spotkały się dwa twierdzenia: „nauczyciel powinien być bardziej zainteresowany motywowaniem i pobudzaniem zainteresowania uczeniem się niż przekazywaniem gotowej wiedzy” ( $M=1,42$; 
Tabela 7. Podstawowe statystyki dla ideologii szczegółowych

\begin{tabular}{|c|c|c|c|c|c|c|c|c|}
\hline & 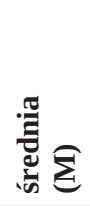 & 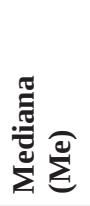 & 䒿 & के & 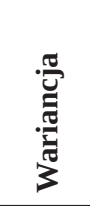 & 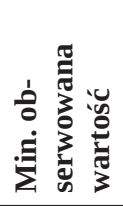 & 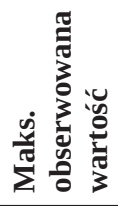 & 乙 \\
\hline fundamentalizm & 2,95 & 3 & 3 & 6,911 & 47,76 & -23 & 19 & 483 \\
\hline intelektualizm & 4,11 & 4 & 4 & 5,549 & 30,79 & -13 & 20 & 488 \\
\hline $\begin{array}{l}\text { konserwatyzm } \\
\text { edukacyjny }\end{array}$ & 6,36 & 7 & 5 & 6,040 & 36,48 & -14 & 24 & 484 \\
\hline $\begin{array}{l}\text { liberalizm edu- } \\
\text { kacyjny }\end{array}$ & 11,94 & 12 & 13 & 5,335 & 28,47 & -7 & 28 & 481 \\
\hline $\begin{array}{l}\text { ideologia eman- } \\
\text { cypacyjna }\end{array}$ & 8,07 & 8 & $5,00 a$ & 5,197 & 28,24 & -15 & 22 & 489 \\
\hline $\begin{array}{l}\text { anarchizm } \\
\text { edukacyjny }\end{array}$ & 5,48 & 5 & $7,00 \mathrm{a}$ & 6,126 & 37,53 & -11 & 25 & 477 \\
\hline
\end{tabular}

a. Istnieje wiele trybów - widoczna jest najniższa wartość.

Źródło: Opracowanie własne.

T.1, skala Le) oraz „kształcenie musi koniecznie służyć wszystkim aspektom doświadczenia dziecka: społecznym, emocjonalnym, fizycznym i poznawczym” ( $\mathrm{M}=1,42 ;$ T.60, skala Lo). W obu przypadkach dominującymi odpowiedziami była „2”, wyrażająca pełną akceptację dla twierdzenia. Ponad 50\% studentów zdecydowało się na udzielenie powyższej odpowiedzi. Ponad $90 \%$ badanych zgadza się („w pełni się zgadzam” + „zgadzam się”) z obydwoma twierdzeniami przypisanymi do ideologii liberalnych, zgodnie z którymi: po pierwsze, zadaniem nauczyciela jest nie tyle transmisja wiedzy, co wspieranie i motywowanie ucznia do rozwijania zainteresowań oraz po drugie, kształcenie ma służyć wszystkim aspektom rozwoju dziecka.

Z kolei zdecydowanie najmniejszą aprobatę badanych wywołuje twierdzenie, że „źródłem szczęścia człowieka jest - ostatecznie - przystosowanie się do przeważających wzorów przekonań i zachowań” ( $M=-0,77$; T.4, skala Ke). Ponad 65\% studentów nie zgadza się z przekonaniem konserwatystów edukacyjnych o zdolnościach adaptacyjnych jako źródle szczęścia człowieka. Kolejne twierdzenia budzące największy sprzeciw badanych to: „formalne kształcenie jest zasadniczo niepotrzebne, a jego wkład w całkowite doświadczenie ludzkie jest niewielki lub żaden” ( $M=-0,45$; T.54, skala A) oraz „studiowanie filozofii jest bardzo ważnym aspektem właściwej edukacji ( $\mathrm{M}=-0,44$; T.37, skala I). Z tym 
ostatnim twierdzeniem - co wydaje się interesujące w kontekście debat o potrzebie prowadzenia zajęć z filozofii nie tylko na studiach wyższych - nie zgadza się co drugi badany.

Najbardziej zróżnicowane opinie wystąpiły w przypadku dwóch twierdzeń: „uczenie się tego, jak myśleć jest ważniejsze niż to, co kto myśli” ( $S D=1,42$; $\mathrm{M}=0,61$; T.43, skala Le) oraz „szkoły powinny kłaść nacisk na krytyczną analizę i ocenianie przeważających przekonań i zachowań społecznych” ( $\mathrm{SD}=1,42$; $\mathrm{M}=0,38 ; \mathrm{T} .84$, skala E). Powyższe twierdzenia najsilniej podzieliły badanych spośród wszystkich twierdzeń umieszczonych w kwestionariuszu; miały największy odsetek osób, które je akceptują lub odrzucają.

Na drugim biegunie zróżnicowania (twierdzenia w najmniejszym stopniu dzielące badanych) znalazły się: opinia głosząca, że „człowiek określa samego siebie zarówno dla siebie, jak i wobec innych ludzi, poprzez swoje działania” (SD=0,72; M=1,30; T. 16, skala Lo) oraz twierdzenie: „Nauczyciel powinien być bardziej zainteresowany motywowaniem i pobudzaniem zainteresowania uczeniem się niż przekazywaniem gotowej wiedzy ( $\mathrm{SD}=0,73 ; \mathrm{M}=1,42$; $\mathrm{T}$. 1 , skala Le). To ostatnie twierdzenie spotykało się z najwyższą aprobatą badanych.

\section{PODSUMOWANIE}

Przeprowadzone badanie miało charakter eksploracyjny, dotyczący jednej z wielu występujących w nauce klasyfikacji podziału ideologii, oraz diagnostyczny. Sądzę, że zaprezentowane w artykule ustalenia mogą mieć istotne konsekwencje zarówno dla pracy badawczej, diagnostycznej, jak i praktyki dydaktycznej oraz pedagogicznej.

Rozkład typów ideologii edukacyjnych wskazuje na wyraźną dominację liberalizmu wśród studentów Akademii Pedagogiki Specjalnej. Z jednej strony wyniki te nie zaskakują. Wcześniej już, w latach 90. XX wieku, kwestionariuszem O’Neilla przebadano studentów pedagogiki na trzech różnych uczelniach. Wyniki badania sprzed ponad 15 lat jednoznacznie wskazywały, iż „wśród studentów pedagogiki, a także wśród studiujących pedagogikę nauczycieli (dominują wśród nich nauczycielki klas początkowych i przedszkola) zdecydowanie przeważają zwolennicy liberalnej ideologii edukacyjnej” (Kwieciński, 2012, s. 60). Przeprowadzone przeze mnie na przełomie 2015 i 2016 roku badanie potwierdza, iż ideologia liberalna w edukacji nadal spotyka się z największą aprobatą. W ostatnich dekadach Polska zadomowiła się wśród państw demokratycznych o liberalnych i postępowych poglądach na funkcjonowanie państwa, w tym także systemów 
edukacji i szkolnictwa. Jest zatem zjawiskiem w pełni zrozumiałym i oczywistym, że płynące z zachodu idee zdobywają swoich popleczników; są coraz bardziej akceptowane i silniej zinterioryzowane, zwłaszcza wśród młodzieży studiującej, jak można przypuszczać, bardziej otwartej, lepiej wyedukowanej.

Jednak z drugiej strony jednoznacznie zdecydowana dominacja nurtu liberalnego przy śladowym ledwie odsetku prawicowych radykałów w obszarze edukacji może też zastanawiać w sytuacji, kiedy różne badania nad młodzieżą oraz obserwacja życia publicznego pokazują, że część młodzieży dryfuje w stronę radykalnie prawicowych środowisk, podpisujących się pod hasłami zdecydowanie antyliberalnymi. Na wyniku badań mogło zaważyć miejsce, w którym zostało ono przeprowadzone. Akademia Pedagogiki Specjalnej należy do najbardziej prestiżowych szkół wyższych oferujących studia pedagogiczne. Także badana populacja: studenci pedagogiki, może znacznie różnić się w swoich poglądach od ogółu młodzieży, która - jak wskazują inne badania (CBOS, 2015) - skłania się ku konserwatywnym poglądom.

Interesującym wyzwaniem badawczym jest, obok poznania ideologii edukacyjnych, także wgląd w opinie młodych na temat konkretnych kwestii związanych z edukacją. Istnieje spore prawdopodobieństwo, iż mimo wyraźnej dominacji „liberalnej ideologii edukacyjnej” znaczna ich część opowie się za wprowadzaniem konserwatywnych rozwiązań do systemu edukacji (np. lekcje religii w szkołach, troska o utrzymanie dyscypliny czy autorytarna rola nauczyciela w klasie). Orientacja liberalna nie musi wcale oznaczać pełnej aprobaty dla liberalnych rozwiązań systemowych czy też popierania liberalnych lub lewicowych środowisk.

Otwartych pytań pozostaje jeszcze wiele. Badania ideologicznych orientacji młodzieży, także pogłębione analizy stosunku młodych ludzi do edukacji, szkoły, celów kształcenia czy treści i programów realizowanych w szkole mogą stanowić źródło inspiracji do dalszej naukowej eksploracji problematyki związanej zarówno ze społecznie pożądanym kształtem polskiego systemu edukacji, jak i poznaniem młodzieży jako pokolenia o specyficznych właściwościach wspólnotowych. W tym kontekście na szczególne zainteresowanie badaczy zasługują fenomen zaangażowania młodzieży w politykę i sprawy publiczne, przemiany w jej postawach i systemach wartości, aspiracjach życiowych i edukacyjnych oraz procesy kształtowania się nowych typów orientacji i rodzajów adaptacji do rzeczywistości społecznej. 


\section{Literatura:}

Centrum Badania Opinii Społecznej. (2015). Komunikat z badań Nr 135. Zainteresowanie polityką i poglądy polityczne w latach 1989-2015. Deklaracje ludzi młodych na tle ogółu badanych. Warszawa: CBOS.

Centrum Badania Opinii Społecznej (2014). Młodzież 2013. Warszawa: CBOS.

Czapiński, J., Panek, T. (red.). (2016). Diagnoza Społeczna 2015. Warszawa: Rada Monitoringu Społecznego.

Gańczarczyk, A. (1994). Orientacje życiowe młodzieży w warunkach transformacji ustroju. Katowice: Wydawnictwo Uniwersytetu Śląskiego.

Kwieciński, Z. (2000). Tropy - ślady - próby. Szkice z pedagogii pogranicza. Poznań -Olecko: Wydawnictwo „Edytor”.

Kwieciński, Z. (2012). Pedagogie postu: preteksty, konteksty, podteksty. Kraków: Oficyna Wydawnicza „Impuls”.

Malewski, M. (2013). „Dorosłość” - kłopotliwa kategoria andragogiki. Teraźniejszość człowiek - edukacja, 3 (63), s. 23-40.

Niezgoda, M. (2014). Młodzież. Kłopotliwa kategoria socjologiczna. Jagiellońskie Studia Socjologiczne, 1, s. 13-34.

O’Neill, W.F. (1981). Educational Ideologies. Contemporary Expressions of Educational Philosophy. Santa Monica: Goodyear Publishing Company.

Szafraniec, K. (2011). Młodzi 2011. Warszawa: Kancelaria Prezesa Rady Ministrów.

Yerli, A.H. (2008). Investigation differences in educational ideologies of school leaders in Mersin in relation to gender, academic degree and in-service training. Pobrano z: http://citeseerx.ist.psu.edu/viewdoc/download;jsessionid=3DEDB5C01E31763A91E AF8FD833C5142?doi=10.1.1.633.5843\&rep=rep1\&type=pdf. 